concentrations when the maximum number of cells are in the circulation? Does rejection occur earlier if allografts are transplanted at night, when the number of $\mathrm{T}$ cells in the recipients' circulation are at their peak ? With respect to the last question, circadian variation in the rejection of rat renal allografts has been described, ${ }^{17}$ and the longest surviving grafts were those inserted when the numbers of circulating lymphocytes were at their trough. Sound data relating time of operation to onset of rejection, or graft survival, in man are lacking, although circadian variation in episodes of renal allograft rejection has been suggested. ${ }^{18}$

We have shown that in any attempt at immunological monitoring account must be taken of circadian variation of lymphocyte subpopulations as a source of variance in results. Conversely, we found the ratio of helper to suppressor cells to be fairly stable in our healthy subjects.

This study was supported by a grant from the Melville Trust. We thank Drs T Abo, C M Balch, and M D Cooper for the gift of the HNK-1 antibody; Professor G D Chisholm for discussion and encouragement; and Mr R A Gray for help with the fluorescence activated cell sorter analysis.

ADDENDUM-Six of the subjects were studied over a further 24 hour period, during which they were deprived of sleep. There were no significant differences in any of the rhythmic variations over this period when compared with the first set of data for these six subjects.

\section{References}

1 Reinherz EL, Schlossman SF. Regulation of the immune responseinducer and suppressor T lymphocyte subsets in human beings. $N$ Eng l f Med 1980;303:370-3.

Herzenberg LA, Herzenberg LA. Analysis and separation using the fluorescence activated cell sorter (FACS). In: Weir DM, ed. Handbook of experimental immunology. 3rd ed. London: Blackwell Scientific, 1978:22.1-22.21

${ }^{3}$ Cosimi AB, Colvin RB, Burton RC, et al. Use of monoclonal antibodies to
$\mathrm{T}$ cell subsets for immunologic monitoring and treatment in recipients of renal allografts. $N$ Engl f Med 1981 ;305:308-14.

3a Ritchie AWS, Gray RA, Micklem HS. Right angle light scatter: a necessary parameter in flow cytofluorimetric analysis of human peripheral blood mononuclear cells. F Immunol Methods (in press).

4 Nelson W, Tong YL, Halberg F. Methods for cosinorrhythmometry. Chronobiologia 1979;6:305-23.

${ }^{5}$ Pownall R, Knapp MS. Immune responses have rhythms: are they important? Immunology Today 1980 October: vii-x.

${ }^{6}$ Bartter FC, Delfa CS, Halberg F. A map of blood and urinary changes related to circadian variations in adrenal cortical function in normal subjects. Ann NY Acad Sci 1962;98:969-83.

${ }^{7}$ Abo T, Kumagi K. Surface studies of immunoglobulins on human B lymphocytes. III. Physiological variations of $\mathrm{SIg}^{+}$cells in peripheral blood. Clin Exp Immunol 1978;33:441-52.

* Abo T, Kawate T, Itoh $\mathrm{K}$, et al. Characterization of rhythms and cell components in circadian variations of human and mouse lymphocytes. Chronobiologia 1979;6:71-2.

9 Abo T, Balch CM. A differentiation antigen of human $\mathrm{NK}$ and $\mathrm{K}$ cells identified by a monoclonal antibody (HNK-1). F Immunol 1981;127: 1024-9.

${ }^{10}$ Abo T, Cooper MD, Balch CM. Characterization of HNK-1+ (Leu-7) human lymphocytes. I. Two distinct phenotypes of human NK cells with different cytotoxic capability. F Immunol 1982;129:1752-7.

11 Abo T, Balch CM. Characterization of HNK-1 + (Leu-7) human lymphocytes. II. Distinguishing phenotypic and functional properties of natural killer cells from activated NK-like cells. F Immunol 1982;129:1758-61.

12 Ritchie AWS, James $K$, Micklem HS. The distribution and possible significance of cells identified in human lymphoid tissue by the monoclonal antibody HNK-1. Clin Exp Immunol 1983;51:439-47.

${ }^{13}$ Ford WL. Lymphocyte migration and immune responses. Prog Allergy 1975;19:1-59.

14 Shohat B, Klein A, Kaufmann $\mathrm{H}$, et al. $\mathrm{T}$ lymphocytes and plasma inhibitory factor in ACTH-dependent Cushings patients. Fournal of Clinical Immunology and Immunopathology 1979;13:452-61.

15 Fauci AS, Dale DC. The effect of in vivo hydrocortisone on subpopulations of human lymphocytes. $\mathcal{f}$ Clin Invest 1974;53:240-6.

16 Yu DTY, Clements PJ, Paulus HE, et al. Human lymphocyte subpopulations: effect of corticosteroids. $\mathcal{F}$ Clin Invest 1974;53:565-71.

17 Ratte J, Halberg F, Kuhl JFW, et al. Circadian variation in the rejection of rat kidney allografts. Surgery 1973;73:102-8.

18 Knapp MS, Cove-Smith JR, Dugdale R, et al. Possible effect of time on renal allograft rejection. $\mathrm{Br}$ Med f 1979;i :75-7.

(Accepted 24 March 1983)

\title{
Renal transplantation in children with occult neurogenic bladders drained by intermittent self catheterisation
}

\author{
O H STANLEY, T L CHAMBERS, B D PENTLOW
}

\begin{abstract}
Children with neurogenic bladders have usually not been considered for renal transplantation because of the potential complications caused by chronic infections of the urinary tract. Two girls with occult neurogenic bladders who were practising intermittent self catheterisation were given renal transplants. Both took prophylactic antibacterial agents after transplantation, and both experienced infections at some stage, but none of these infections produced a deterioration in renal function. In one patient creatinine clearance fell and signs of
\end{abstract}

Regional Department of Paediatric Renal Dialysis and Transplantation, Southmead Hospital, Bristol BS10 5NB

O H STANLEY, MRCP, paediatric registrar

T L CHAMBERS, FRCP, consultant paediatrician

B D PENTLOW, FRCS, consultant transplant surgeon

Correspondence to: Dr T L Chambers. obstruction appeared, but this was because the patient had been catheterising herself only two or three times a week. When she resumed catheterisation four times a day creatinine clearance rose and the urographic and renographic appearances returned to normal.

These results suggest that, with adequate catheterisation and urinary chemoprophylaxis, infection is not a particular problem in children with bladder dysfunction who undergo renal transplantation.

\section{Introduction}

Intermittent clean self catheterisation is an accepted form of managing neurogenic bladders in childhood which does not produce major problems arising from sepsis. ${ }^{1}$ It might be supposed that the immunosuppression associated with renal transplantation would lead to problems with infection. We describe two children with occult neurogenic bladders who received renal transplants while practising intermittent self catheterisation after micturition. 


\section{Case 1}

At the age of 11, after a five year history of enuresis and urinary tract infection associated with left ureteric reflux and treated by ureteric reimplantation and later left nephrectomy, a final micturating cystourethrogram in this girl showed a dilated and diverticulated bladder. No abnormal neurological signs were detected. She started self catheterisation after micturation but required haemodialysis after one year and received a live donor transplant at the age of 12 years 9 months. The graft was placed in the left iliac fossa: the ureteric anastomosis was made using the Leadbetter-Politano technique and was splinted on a size 6 Tizzard catheter.

Three months after transplantation her creatinine clearance fell from 100 to $60 \mathrm{ml} / \mathrm{min} / 1.73 \mathrm{~m}^{2}$; intravenous urography and ultrasound examination showed dilatation of the pelvicaliceal system of the transplanted kidney (see figure), and an isotope renogram with

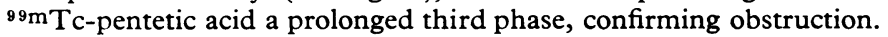
She confessed that she had been catheterising herself only two or three times a week; her urine grew no pathogens. A return to self catheterisation four times a day was followed by a normal clearance and normal urographic and renographic appearances (see figure). Twenty four months after transplantation her creatinine clearance was $94 \mathrm{ml} / \mathrm{min} /$ $1.73 \mathrm{~m}^{2}$ and she was practising self catheterisation three or four times a day.

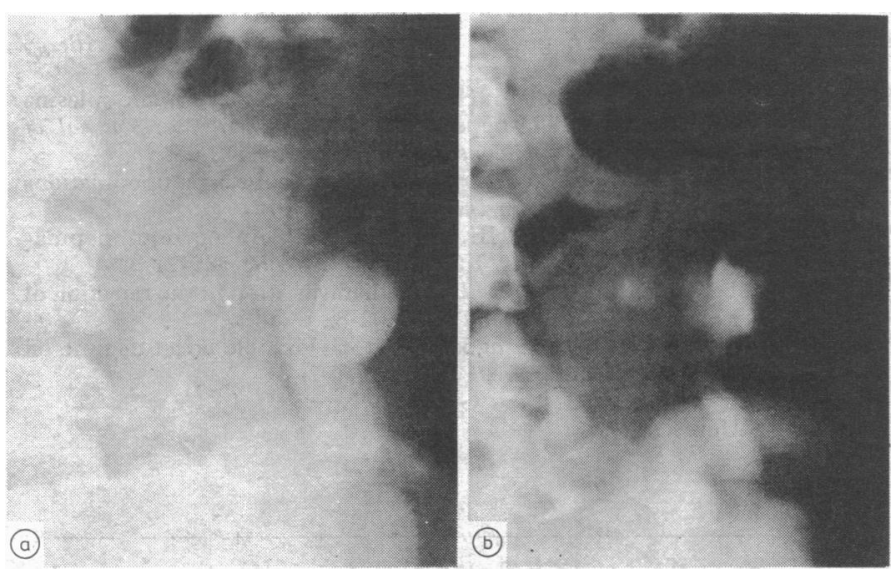

Case 1. Intravenous urograms, taken 20 minutes after injection of contrast media, of transplanted kidney (a) three months after transplantation, with sporadic self catheterisation and deteriorating function; and $(b)$ two months later, when regular self catheterisation had been re-established and function restored.

\section{Case 2}

At the age of 4 a micturating cystourethrogram in this girl showed a large diverticulated bladder. Bladder neck surgery was unsuccessful and her enuresis and repeated urinary tract infections continued. Her renal function deteriorated and at $7 \frac{1}{2}$ years she started self catheterisation after micturition, progressing to chronic ambulatory peritoneal dialysis and a cadaveric renal transplant within two years. Twelve months after transplantation her clearance was $120 \mathrm{ml} / \mathrm{min} /$ $1.73 \mathrm{~m}^{2}$; she was practising self catheterisation five times a day. Her enuresis was improving with imipramine.

\section{Discussion}

Renal transplants have been performed in patients with ileal conduits, ${ }^{24}$ in patients with bladders with previous urinary diversion, and in those who have undergone surgery for obstruction of the lower urinary tract. ${ }^{3}$ Chronic infection together with multiple diverticula and scarring have, however, been considered to be contraindications to transplantation. ${ }^{3}$

Both our patients have taken prophylactic antibacterial agents since transplantation. They are now taking nitrofurantoin 100 mg nightly, with an immunosuppression regimen of prednisolone $15 \mathrm{mg}$ on alternate days and azathioprine $2 \mathrm{mg} / \mathrm{kg}$ daily. During the first month after operation each child had one symp- tomatic and one asymptomatic urinary tract infection. In the first patient Staphylococcus epidermidis was isolated from the urine on both occasions and once from the blood. Escherichia coli was isolated from the urine but not the blood of the second patient on both occasions. Subsequently the first patient has had two asymptomatic urinary tract infections (Staph epidermidis) and the second has had an asymptomatic infection with Streptococcus faecalis and another with Serratia marcescens, which was associated with systemic upset but responded to 12 days' treatment with nalidixic acid. In neither patient did the infection produce a deterioration in renal function.

These two cases suggest that, with adequate self catheterisation and urinary chemoprophylaxis, infection in children with bladder dysfunction who have undergone renal transplantation is no greater problem than in the transplant recipient with normal bladder function and that acceptable clearances can be maintained. Irregular self catheterisation was associated with the appearance of reversible obstructive features and a diminution of function in the transplanted kidney (case 1). Satisfactory self catheterisation in boys is also well described ${ }^{5}$ and transplantation in such cases should be feasible.

We thank our paediatrician and urologist colleagues in the region for referral of patients.

\section{References}

${ }^{1}$ Lapides J, Diokno AC, Gould FR, Lowe BS. Further observations on selfcatheterization. $\mathcal{F}$ Urol 1976;116:169-71.

2 Kelly WD. Ileal urinary diversion in conjunction with renal transplantation. Lancet 1966; : $: 225-6$.

${ }^{3}$ Firlit DF. Use of defunctionalized bladders in paediatric renal transplantation. F Urol 1976;116:634-7.

4 Krieger JN, Stubenbord WT, Vaughan ED. Transplantation in children with end stage renal disease of urologic origin. 7 Urol 1980;124:508-12.

5 Scott JE, Deegan S. Management of neuropathic urinary incompetence in children by intermittent catheterization. Arch Dis Child 1982;57: 253-8.

(Accepted 13 April 1983)

ONE HUNDRED YEARS AGO That a holiday is a necessity, and not merely a luxury, is a fact which it especially behoves members of our hard-working profession to remember in the regulation of their own lives, as well as in their dealings with their patients. For the brain-worker, periodical remission of accustomed toil has always been a necessary condition of continued vigour; for him, the heightened tension of modern life has especially accentuated the need for occasional periods devoted to the recreation and the re-accumulation of energy. The cogent physiological principles and practical purposes of systematic holidays are generally admitted. All workers, if they are to last, must have holidays. For some persons, and for some occupations, frequent short holidays are best; with other natures, and in other circumstances, only comparatively long periods of release from routine are of service. Few real workers, if any, can safely continue to deny themselves at least a yearly holiday. Mere rest, that is mere cessation from work, while it is better than unbroken toil, does not recreate the fairly vigorous so thoroughly as does a complete change of activity from accustomed channels. For the strong worker, either with brain or muscle, diversion of activity recreates better than rest alone. The whole body feeds as it works, and grows as it feeds. Rest may check expenditure of force, but it is chiefly by expending energy that the stores of energy can be replenished. We mostly need holidays because our ordinary daily life tends to sink into a narrow groove of routine exertion, working and wearing some part of our organism disproportionately, so that its powers of work and its faculty of recuperation are alike worn down. In a well arranged holiday, we do not cease from activity, we only change its channels; with such change, we give a new and saving stimulus to assimilation, and the transmutation of its products into force. As a rule, the hardest workers live longest, but only those live long who sufficiently break their wonted toil by the recreating variety of well timed and well spent holidays. (British Medical fournal, 1883;ii:175.) 